\title{
Ah ch'ibal canob: rethinking celestial animals in the Paris Codex 23-24
}

\author{
Stanislaw Iwaniszewski
}

\begin{abstract}
:
Pages 23 and 24 of the Post-Classic Paris Codex contain figures of thirteen celestial beasts interpreted as Maya zodiacal constellations. Traditional scholarship has long attempted to identify those animals with Western zodiacal constellations. Assuming this is correct, it would mean the Maya had chosen thirteen figures or names to represent groupings of stars located on or near the ecliptic. Thus, contrary to twelve Western (Greek-Roman) zodiacal constellations, each representing about $30^{\circ}$ of the ecliptic, the hypothetical Maya constellations would occupy 13 locations within the ecliptic band covering only $27^{\circ}-28^{\circ}$ of its circle. Implicit in this is the idea that Maya zodiacal animals constituted forms of being similar to those played by Western zodiacal ones. However, this almost automatic identification of the Paris Codex figures with the Western zodiac creates an epistemic barrier in understanding what celestial beasts could mean for the Maya. To describe them in a purely astronomical light may lead us to impose our own Western concepts upon theirs, merging different cultural concepts on one epistemic level, thus restricting the further exploration of ontologically different perspectives.
\end{abstract}

This paper aims to clarify the nature of the animals pictured in the Paris Codex 23-24.

Keywords: Paris Codex, Maya constellations, wahy entities

\section{Resumen:}

AH CH'IBAL CANOB LA RECONSIDERACION DE LOS ANIMALES CELESTES EN EL CÓDICE DE PARIS 23-24

Las páginas 23 y 24 del Códice postclásico llamado Paris contienen figuras de trece bestias celestes interpretadas como constelaciones zodiacales mayas. Los investigadores han intentado durante mucho tiempo identificar a esos animales con las constelaciones zodiacales occidentales. Suponiendo que esto sea correcto, significaría que los mayas habían elegido trece figuras o nombres para representar asterismos y grupos de estrellas ubicadas en o cerca de la eclíptica. Por lo tanto, contrariamente a las doce constelaciones zodiacales occidentales (greco-romanas), cada una representando aproximadamente $30^{\circ}$ de la eclíptica, las hipotéticas constelaciones mayas ocuparían 13 lugares dentro de la banda eclíptica, cada una cubriendo

Stanislaw Iwaniszewski • Escuela Nacional de Antropología e Historia - Instituto Nacional de Antropología e Historia, Ciudad de México and Państwowe Muzeum Archeologiczne, Warszawa, email: siwanisz@yahoo.com

https://orcid.org/0000-0002-7132-5158 
$27^{\circ}-28^{\circ}$ de su círculo. Implícita en esto está la idea de que los animales zodiacales mayas constituían formas de ser similares a las jugadas por los zodiacales occidentales. Sin embargo, esta identificación casi automática de las figuras del Códice de París con el zodíaco occidental crea una barrera epistémica para comprender lo que las bestias celestiales podrían significar para los mayas. describirlos bajo una luz puramente astronómica puede llevarnos a imponer nuestros propios conceptos occidentales sobre los suyos, fusionando diferentes conceptos culturales en un nivel epistémico, restringiendo así la exploración adicional de perspectivas ontológicamente diferentes.

Este artículo tiene como objetivo aclarar la naturaleza de los animales representados en el Códice de Paris 23-24.

Palabras clave: Códice de Paris, constelaciones mayas, entidades wahy

\section{Introduction}

Pages 23 and 24 of the Post-Classic Paris Codex contain figures of thirteen celestial animals ("beasts") that have long been regarded as representing Maya zodiacal constellations (Figure 1). Those highly damaged figures display various zoomorphic and anthropomorphic beings biting eclipse glyphs hanging from the sky- and zigzag- bands. Scholars have long attempted to identify those figures with Western zodiacal constellations assuming the Maya divided the ecliptic into a series of thirteen equal division star groupings (for the history of research, consult Bricker and Bricker 2011: 708-729).

Grouping particular stars into constellations was undoubtedly the activity undertaken by various Mesoamerican peoples long before assembling the tables in the form of the codex. Unfortunately, the evidence for the Classic Maya names or figures of ancient star groupings or constellations is very sporadic and incomplete (e.g., Chinchilla Mazariegos 2011: 191-199). Moreover, even though Colonial sources provide some clues to successful identifications, the literate Maya elite quickly adopted European astronomical concepts following the Conquest, leaving few reliable connections to their codices' heavenly information. Similarly, while the current ethnographic record allows for particular identifications, the influence of the modern West calls for attention. Thus, only a limited number of iconographic and lexical clues may help reconstruct the Classic Maya constellations.

A tentative reconstruction of the Paris Codex zodiacal constellations that produced modern scholarship also based on their associations with their apparent analogs found on the Nunnery Annex at Chichén Itzá, the Throne Inscription on the Palace of Governor at Uxmal, and the like (Smither 2012-13; Bricker and Bricker 2011: 708-711; 836-839). Assuming this is correct, it would mean the Maya had chosen thirteen figures or names to represent groupings of stars located on or near the ecliptic. The possibility that the animals pictured in the Paris Codex could have represented zodiacal or circum-zodiacal constellations perpetuated the idea that the Maya had constellations spaced across the heavens directing research attention to their identifications with Western constellations. Our vision of supposed Maya zodiacal constellations has long been shaped by the efforts of modern scholarship 

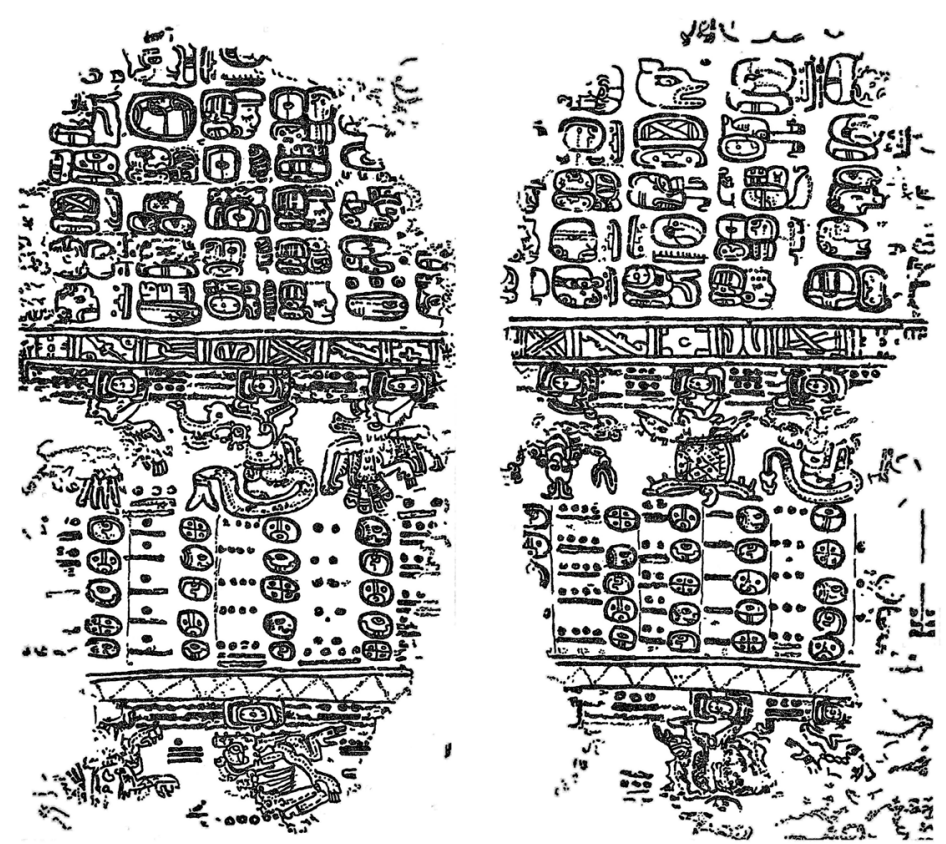

Figure 1. Pages of the Paris Codex 23 and 24 with animal constellations. (After Villacorta and Villacorta 1930:220 and 222).

to accommodate them vis-a-vis the Western zodiac. However, to describe them in a purely astronomical light may lead us to impose our own Western concepts upon theirs, merging different cultural concepts on one epistemic level, thus restricting the further exploration of ontologically different perspectives.

\section{The structure of Paris Codex 23-24}

The information on pages 23 and 24 of the Paris Codex consists of visual imagery and a calendrical table that have long been understood as representing a hypothetical Maya zodiac (Spinden 1915). Their content conforms to the pattern of Maya manuscripts which combines the hieroglyphic text with calendrics and iconography. The hieroglyphic text arranged in six and seven columns is set in the upper part of both pages. The number of rows is, however, less certain (seven or eight). The text probably gives some of the "celestial animals" names and deals with omens or predictions (Love 1994: 89; Bricker and Bricker 2011: 736-745; Špoták 2015: 375-382). Though at first glance, the number of columns of glyphs matches the number of the thirteen celestial animals, the exact meaning of the text is still not well understood (Love 1994: 89; Špoták 2015: 375).

Both pages accommodate one table read from the upper right on page 24 to the lower left on page 23. The numbers are displayed in five rows running through 
both pages and forming thirteen columns between the upper and lower skybands. The table starts at the top right corner on page 24, with the reconstructed day 12 Lamat. Each row of day signs marks thirteen 28 -day periods, represented by the columns, totaling 364 days, a period called "computing year" by specialists. In total, the table features five rows, each completing an interval of $13 \times 28$ days for a total of 1820 days, matching seven tzolk'ins ( 7 × $260=1820$ days).

As stated above, the table is visually divided into sections through two skyband motifs that run across both pages. The upper one represents a body of a bicephalic sky monster (Carlson and Landis 1985: 138; Love 1994: 89-90), and the lower one contains a dotted zigzag line inside. Seven animal figures hang from the upper skyband while six additional animals from the lower band.

Below each skyband there are eclipse signs with black bar-and-dot signs for " 8 " between them. Thus, there are two " 8 " below the upper skyband (one eight over another eight) and only one " 8 " preserved below the lower skyband. Following Kelley (1976:49-50), scholars usually agree that the number in question is 8.8 (in the Maya vigesimal numerical system), or $8 \times 20+8=168$ days, implying that celestial beasts hanging from eclipse signs (some now effaced) stay 168 days apart.

Despite the partial damage of the codex pages, there is little doubt that thirteen, not fourteen, animal figures formed the table (Bricker and Bricker 2011: 697 note 1; Špoták 2015: 358). Following provisional identifications made by Bricker and Bricker (2011: 706), the celestial animals in question are (moving from the right to left, from the upper to lower register): bird, rattlesnake, turtle, scorpion, bird (owl), fish-snake (shark), bird (vulture), frog, bat, peccary, deer, humanlike skeleton, and jaguar. Each celestial beast has its mouth or beak open, apparently attempting to bite or consume the eclipse glyph placed above them. As mentioned above, traditional scholarship has long been tempted by the possibility of identifying them with Western zodiacal constellations.

Various sections found in Maya codices attest to the use of a 364-day count. Although the 364-day count was shorter by one day from the Maya haab, its use was probably inspired by the compatibility with tzolk'in since five 364-day calendars are equal to seven $t z o l k$ 'in counts $(5 \times 364=7$ x $260=1820$ days). Like tzolk'in, the 364-day interval breaks evenly in 13-day periods count or trecenas. However, the schematic layout of the Paris Codex table emphasizes the importance of 28-day intervals. It means the dates arranged in thirteen columns stay 28 days apart. Thus, we deal with the count of 13 times 28 days in each row, not 28 times 13 days. Each column shares the same day number. Only five different day names are used (Lamat, Kib, K'an, Eb, and Ajaw). Now, connecting thirteen columns describing 28-day intervals with the thirteen figures of animals would reveal the table's function as a kind of a zodiacal calendar. According to this interpretation, each animal would represent asterisms near or upon the ecliptic, covering 28 days. 


\section{Astronomical interpretation of animals}

In this paper, I am following the solution proposed by Bricker and Bricker (2011). The authors suggest that the animals represent constellations or star clusters arranged in pairs that simultaneously rise and set at 28-day intervals.

Since the horizon is a great circle that roughly cuts the heavenly sphere in two, at any moment, half of the ecliptic (= zodiacal belt) is placed above the horizon and the other half - below. The ecliptic circle representing the Sun's apparent path during the year, observed from the Earth's surface, oscillates around due East and West points, reaching the extremes at solstices. Within the tropics, where each celestial object rises and sets almost vertically, the simultaneously rising and setting circum-ecliptic stars will approximately be $180^{\circ}$ apart. The scheme implied by Bricker and Bricker divides the celestial sphere into nearly symmetrical halves. While one cluster of stars rises in the dawning sky, the other gradually sinks below the western horizon. However, to be visible, both hypothetical constellations, the rising and setting ones, need to be observed until the stars disappear from the gradually brightening sky. Since both constellations are several degrees above the horizon, then, logically, the distance between the selected pairs of constellations is less than $180^{\circ}$ /days ${ }^{1}$. This situation seems to confirm Kelley's (1976: 49) argument that the 168-day distance between the pictures cannot denote opposite sides of the sky. Bricker and Bricker (2011: 731) obtained the best fit with the celestial animals when they examined the pairs of constellations at dawn rather than at dusk, about one hour before the sunrise, the moment, which, for the latitude of northern Yucatan, occurs shortly before the beginning of the nautical twilight. The following formula gives the duration of twilight':

Before searching for correlations with the Western zodiac, Bricker and Bricker (2011) started with the assumption that they could quickly identify three Maya constellations. They presumed that the scorpion image is the Scorpio constellation, the rattlesnake represents the Pleiades, and Orion (or some part of Orion) is the turtle.

Beginning with the day 12 Lamat and equating this day with the date 9.16.10.4.8 12 Lamat 1 Muwan from the eclipse table of the Dresden Codex, Bricker and Bricker started the count with the dawn on November 10, 755 CE (correlation constant 584283). They observed that the stars of Libra were rising on that day while the Pleiades were about to set. Identifying the Pleiades with the rattlesnake, they found that the first celestial animal, whose figure is now effaced, reasonably represents a bird (that may be observed on the skyband from the Nunnery at Chichen Itza).

Noting that $1 \mathrm{Kib}$ in the second column is 28 days after 12 Lamat, Bricker and Bricker observed the sky at dawn on December 8, 755, 28 days after November 10, $755 \mathrm{CE}$. They noticed that while the turtle (associated with Orion) was setting, the scorpion (identified with Scorpio) rose. Applying this model to the cycle of 364 
days, Bricker and Bricker tracked the movement of the constellations at dawns of each of the 28-day intervals, from November 755 to October 756, finding correlations with celestial animals.

Furthermore, Bricker and Bricker (2011: 745) propose that the hieroglyphic text recorded in the upper register in the form of 13 columns provides the names of constellations. The 168-day intervals, written as 8.8 in Maya numerical notation, would mark the period between the rising and setting in the morning before sunrise of the same constellation. The 84-day intervals (a half of 168 days) would describe the periods between rising and culminating at dawn or between culminating and setting at dawn of the same constellation.

However, the idea that adjacent animal figures represent pairs of star clusters or constellations visible on opposite horizons simultaneously at dawn leaves several unsolved questions. For example, the use of equal 28-day intervals may imply that these constellations were approximate of similar size. Otherwise, the Sun would be assumed to move uniformly along the zodiacal belt, and all constellations yield equal length.

\section{In search for a status of celestial constellations}

Perhaps an ontological approach to the role of the sky in ancient and nonwestern societies should start with the assumption that the peoples and other living and non-living components of their surroundings constitute the same existential sphere (Webmore and Witmore 2008). In such a lifeworld, the celestial bodies and phenomena are perceived as being subjected to the same rules as humans (see Iwaniszewski 2009, 2011). Since ontologies involve critical aspects of social life, such as personhood and the idea of a community of acting human and non-human agents, humans may think of celestial bodies as entities endowed with human-like properties. The main task of cultural astronomy would be to bring to light the diverse ways celestial bodies and events are thought to operate in human environments. Cultural astronomy should examine how humans perceive, choose and select certain qualities of celestial objects and relations and how they use them to weave permanent or ephemeral relations with their heavenly environment.

The problem is that describing the animals as "zodiacal constellations" prevents us from discussing what they were to the Maya. This circumstance requires explanation. The term "zodiacal constellations" raises immediate difficulties in that zodiacal constellations may be regarded as forming a class of celestial objects identifiable from the same universal or objective perspective. To speak of "zodiacal constellations" is to discuss entities that have been given a priori astronomical definition of such. Thus, the "zodiacal constellations " of which I speak may usually be understood as referring to the groupings of stars located within the yearly path of the Sun in the sky. The cognitive operation through which those stars are identified, classi- 
fied, and separated from others is made from the same epistemological plane: the ecliptic. Thus, at first glance, the very term "zodiacal constellation" implies, a priori, that European and Maya star groups represent the same referential framework. The disciplinary definition of "zodiacal constellations" is above all the subject matter of astronomy, which deals with the objects and phenomena situated in the external world. Cultural astronomy cannot restrict its scope to the astronomical treatment of celestial bodies and events because astronomy is only one of the forms of human engagements with the sky.

Moreover, from the standpoint of anthropological theory, cultural astronomy examines the uses and meanings of celestial objects and events arising from their relationships with other entities and human societies. Therefore, whatever Maya "zodiacal constellations" might be, they may share some of the meanings of the zodiacal constellations conferred to the zodiacal constellations in the early 16thcentury European astronomy but certainly do not coincide with them. Thus, from the point of view of cultural astronomy, the concept of a "zodiacal constellation" may preclude efforts to make sense of some of their meanings. Unfortunately, modern scholarship seems to keep this tendency, devoting much effort to identifying Maya constellations with Western ones (Kelley 1976; Paxton 1992: 235-237; Love 1994; Bricker and Bricker 2011).

On the other hand, to speak of European and Maya zodiacal constellations is to speak of diverse subjective and partial points of view on the same objects of the external universe. This universe remains indifferent to those descriptions; it constitutes a single reality following general laws, while cultural approaches to them are many (e.g., Viveiros de Castro 1998, 2004). Thus, cultural understandings of zodiacal constellations would only produce variations on the same topic. This kind of cultural relativism only reinforces the idea of multiculturalism, as expressed by Viveiros de Castro $(1998,2004)$. All peoples live under the same sky, or there is only one common material world and different forms of apprehending it. This standpoint invites us to think that whatever the Maya thought about zodiacal stars, they would automatically become molded in the guise of the Western zodiac. This almost automatic identification of the Paris Codex images with the Western zodiac creates an impression that they share the same ontological plane. Such an attitude leads scholars first to identify the animals to render them in the proper order and then plot the animals against the ecliptic stars. Though the Maya zodiacal constellations might be ontologically different from the European, scholarship is here limited to concluding that the Maya classified or named the groups of stars located in the ecliptic, paralleling, for example, the efforts of the Babylonians, Greeks, and Romans. The twelve Western constellations occupying twelve (equal) parts of the zodiac are simple compared to thirteen Maya constellations also occupying thirteen (equal) parts of the ecliptic. The results of such comparative studies would mean that the Maya and Europeans possessed two different schemes of celestial cartography. 
The division of the ecliptic into 12 or 13 segments may reflect their differences in time-reckoning systems, while the figures of animals or other entities may refer to their mythologies. However, as given by Bricker and Miram (2002: 37) and Bricker and Bricker (2011: 63, 729-731, 836), the interpretation of those constellations suggests that the Maya were interested in observing the disappearance/reappearance of constellations in the west/east before sunrise, while the European zodiac served to register the positions of the Sun within it $^{3}$.

Though Bruce Love (1994: 89), following Barbara Tedlock's ethnographical work in Momostenago (Tedlock 1992a:182; 1992b:29), assigned to the hypothetical zodiacal constellations from the Paris Codex the term of "signs of the night" (retal $\left.a k^{\prime} a b^{\prime}\right)$, implying they were used to time ritual events, phonetic readings of the hieroglyphic text (Paxton 1992: 224-231; Bricker and Bricker 2011: 736-745; Špoták 2015: 375-382) do not allow us to identify them emically. The text is damaged with several missing glyphs, and scholars suppose it must have shown references to deities, time intervals, and constellations (Paxton 1992: 230).

As for the phonetic reading of the hieroglyphical text, Bricker and Bricker (2011) and Špoták (2015) produced differently nuanced results. Bricker and Bricker (2011: 745) proposed to resolve the issue by identifying the names of some constellations with the names of particular deities and correlating them with the pictures of animals. On the other hand, Špoták (2015:375-382) argued that the text recorded predictions for particular years, accepting earlier Love's (1994: 102) proposal to treat the constellations as "yet another class of spirit beings." Also, Bricker and Bricker (2011: 365-366) observe that animals representing constellations with solar glyphs in their jaws are similar to the images of animals biting the Sun or the Moon during eclipses as found in early Colonial sources. They even call them "zodiacal beasts".

\section{Biting as a mode of acting of celestial animals}

Since the lack of the generic name identifying constellations as separated entities obscures their original character, it may be helpful to examine how they are represented in the codex.

Considering constellations' animacy, the Maya depicted their figures in the form of animals biting or devouring eclipse signs. Though the movement of the celestial vault could have been significant in determining their animacy, the figures portray animals attempting to bite or devour the sign. The addition of mouths, claws, teeth, beaks and the like makes the animal figures alive. So, how they behave towards eclipse glyphs is indicative of their personhood. According to Descola (2014), the properties of persons and their relationships result from combining modes of identification and relation. So, through interaction, people apprehend them as clusters of features or qualities that can exhibit their properties depending on how they conceive their modes of being. By tracing the conditions by which 
such entities have effects, we may confine them to a particular essence, place, and time. As identified by Bricker and Bricker, all animals appear to share humid, cold, or dark places, or, as prey birds and a human-like skeleton, seem to be associated with death. Still, other creatures (like jaguar and owl) are also associated with nighttime activities. Each animal has its mouth, claws, or beak open, apparently attempting to bite or consume the eclipse glyph. In their commentary on the Codex Paris, Bricker and Bricker (1992: 153-154; 2011: 717) observe that both the zodiac pages and the Dresden Codex Eclipse Table share the same 12 Lamat base date, so some association with the eclipses seems to be implicit. What remains problematic is the relationship of the eclipse glyphs with animals. The glyphs in question essentially represent solar eclipses (Bricker and Bricker 2011:695), which contradicts the fact that solar eclipses are observable during the daytime.

Nevertheless, as described above, the hypothetical constellations represented by the animals refer to the moments when the Sun is still well below the horizon. So, at least on this level, eclipse glyphs cannot refer to the predictions of actual solar eclipse possibilities. Furthermore, as Christian Prager (2006) and Bruce Love (2018) noticed, eclipse glyphs do not always mean eclipsed celestial bodies. In this context, biting, swallowing, or eating appear to be crucial activities acknowledged as vital and sufficient on their own terms. Thus, nocturnal, predatory, or dangerous creatures inhabiting dark, cold, and humid locations represent the entities that embody celestial constellations (see also Love 1994: 93). By picturing them all engaged in biting activities, the designers of the table aimed to restrict their agency to just one sole activity. All depicted animals bite or attempt to bite the eclipse glyphs. Except for the scorpion that attacks the eclipse glyph with a tail, all other animal figures use their jaws or beaks. By juxtaposing the animals with eclipse glyphs, the Maya scribes emphasized that these animals are threatening ones. Finally, by inserting the calendar table, they showed the modes of being depended on actions performed at calendrically defined cycles (28- and 364-day intervals).

The second step of my analysis considers the linguistic and iconographic information on the early colonial Maya beliefs associated with eclipses. The figures of animals biting eclipse glyphs resemble the most common explanation for eclipses among the Maya: an animal eating or swallowing the Sun or the Moon (Closs 1989; Milbrath 1999: 25-27, 111-113). As it is well known, the Yucatec Maya term for eclipses is chi'bil ("to bite"), attributing (partial) eclipses to certain animals that bite, eat or swallow the Sun and the Moon. Various colonial and current ethnographical accounts describe a jaguar, a snake, a lizard, a Xulab or red ant, a scorpion, or evil animals as eclipse agents (Closs 1989: 396-398; Milbrath 1999: 26, 111; Vail and Hernandez 2013: 324-329). Three of these agents figure on pages 23 and 24 of the Paris Codex. Sometimes the eclipse agent was the Moon (Milbrath 1999: 26, Bricker and Bricker 2011: 304-305). What is important here is the belief that eclipses were caused by an animal biting or threatening the Sun or Moon. A further note on 
eclipses is found in Diccionario Maya Cordemex. When the Sun is being eaten, "the arc of the umbra on an eclipsed sun is similar to the marks left by the teeth in things which are bitten" (Barrera Vásquez 1980: 93).

Furthermore, it is necessary to note that the same term ch'ibal denotes both "to bite" and "pain" and in particular "stinging pain" or "the sore and stinging it seems to bite" (Barrera Vásquez 1980: 92). Also, the bite (like snakebite) causes heat (Chevalier and Sánchez in Bain 2003: 106)4. Therefore, semantically speaking, snakebites may embody a specific kind of pain, a "burning pain" or a "biting pain".

\section{Identifications arising from Colonial sources}

As evidenced by the Yucatecan Books of Chilam Balam, the Maya elites displayed great interest in European conceptions of cosmology, astronomy, and astrology (Montoliú Villar 1989). As recent scholarship has shown (Chavez Guzman 2006; George-Hirons 2015; Knowlton 2015), astronomical texts within the Chilam Balam manuscripts adopted much information from Spanish reportorios de los tiempos or lunarios. In exploring all possible similarities and differences between these traditions, the colonial-era Maya elites accessed them within the context of their own knowledge. Assuming that these books today serve as a bridge between Maya Classic and Postclassic cosmology and astronomy and their reinterpretations in colonial times, it is possible to examine how new European sources were understood and adopted to Maya narratives. So, whether or not Maya zodiacal constellations existed, the Chilam Balam manuscripts provide a framework by which this can be examined. In other words, if the Maya had their counterpart to the Western zodiac, this would undoubtedly be elucidated, included in comments. The content of these books shows that the Maya were interested in medical astrology, adopting the European use of planets and zodiacal constellations or signs as agents causing different kinds of illness. For example, a section in the Chilam Balam of Kaua describes the illness-causing entities as ah chibal canob, which Bricker and Miram (2002: 97) translated as "the wild animals of the sky" and Chávez Gúzman (2006: 128) as "burning pain that bites." These fiery animals inhabit the place of the white cloud (sac muyal), "above the horizon" (Bricker and Miram 2002: 97), and produce cold and pain after the sunset (Bricker and Miram 2002: 99). A similar note of Chilam Balam of Mani (Códice Pérez 1949: 58-59) tells about the beasts that inhabit the sky (the white nest in the sky), spread on Earth at dawn, when the cold air descends, causing specific diseases. Both descriptions show connections between the terms or expressions like chi'bal, "to bite," chi'ibal "sting pain", ah ch'ibal "thing that bites or stings, beast", and ch'ibil k'in/ch'ibil u "eclipse the sun/eclipse the moon" (Barrera Vásquez et al. 1980: 92-93). The terms used here connect them with expressions of inflammations such as burning or poisonous pain caused by wahy beings (Helmke and Nielsen (2009: 67). It would mean that ah ch'ibil canob, known from the books 
of Chilam Balam, could be identified as a kind of wahy spirits known from the Classic period (250-900 CE) painted pottery (Grube and Nahm 1996; Stuart 2005; Shesheña 2010). They would correspond to the nahuals of central Mexico (see also Knowlton 2015: 576).

It seems that by interrogating the similarities and differences that existed between celestial animals and European zodiacal signs, the Maya authors of the Books of Chilam Balam realized that both traditions shared beliefs in the origins of sickness. This is the reason, I suspect, explaining why they inserted the mention of celestial animals in sections reporting the movements of planets and zodiacal signs that could all have contributed to one's sickness.

In addition to identifying celestial animals with wahy beings and zodiacal signs, another tradition links celestial animals to the angels. This relevant information is provided by the Morley Manuscript (278-279) made between 1760 and 1780 but compiling some information from the turn of the 16th and 17th centuries (Whalen 2003: 2-8). The manuscript records the term balcheob caaneob (ba'alche', "animal, beast" (Barrera Vásquez et al. 1980: 35), a synonym of ah ch'ibal "beast"), which describes the angels (angelob) as canil uinicob, u balcheob caanob, ekob = "the heavenly persons, the creatures of the heavens, the stars" (Whalen 2003: 219), or "the heavenly people, the wild animals of the heavens, the stars" (Knowlton 2010: 112). Thus, angels are naturally celestial beings. However, as Knowlton (2010: 144-145) observes, the Morley manuscript refers to the fallen angels rather than angels seated in the highest celestial layers. It is said that when they fell to Earth, Lucifer's angels entered plants, holes in the Earth, and winds that "capture someone so that he may become sick" (cu chucic uinic ca kohanac, see Bricker and Miram 2002: 292; Knowlton 2010: 145). This notion would imply that the Maya compared the angels with the stars, so following the Chilam Balam of Kaua, they conceived angels as "wild animals of the heavens" responsible for certain diseases (Knowlton 2010: 112).

As stated above, the identity of the animal figures representing zodiacal constellations remains obscure, with their names poorly understood (Bricker and Bricker 2011: 740-745; Špoták 2015: 375-382). Lacking emic terms, their identity cannot be assumed, but examining their acting mode may help us infer their character.

The occurrence of an eclipse of the sun or moon one or two times a year stands out among the most dramatic celestial events. Eclipses were often regarded as portents of bad events forcing the people to act to avert calamities ritually (Milbrath 1999: 25-27). Therefore, the juxtaposition of animal figures with solar eclipse glyphs should allow us to explore their ontological status.

Like other Mesoamerican peoples, the Maya generally observed eclipses with great fear; the animals biting or devouring the sun were univocally considered noxious and poisonous creatures. The ethnohistoric and ethnographic records show that the rounded shadow of the moon or Earth projected upon the sun or moon at the time of eclipses led the Maya to explain this shadow as a bite. Thus, the metaphor of the 
sun or moon being bitten throws additional light on what celestial animals identified with zodiacal constellations might mean to Maya scribes and skywatchers. The conflation of biting (the sun or moon) with the notions of pain, or sharp pain, allows us to treat them as entities similar to the other wahy beings. So aside from being eclipse agents, such as ah chibal canob, they were responsible for a category of diseases described as "pain" and "sharp pain", such as burning itchiness. Similarities between the harmful effects that ah ch'ibal canob entities might provoke in humans and the effects produced by representations of zodiacal signs in Chilam Balam of Kaua (Bricker and Miram 2002: 83, 9599; Helmke and Nielsen 2009: 59-62) allows us to compare them with the malevolent intentions of wahy beings (Grube and Nahm 1994; Stuart 2005, Shesheña 2011). Thus, the zodiacal constellations identified with ah ch'ibil canob and European zodiacal signs belonged to a category of wahy-like beings that should be avoided. This is why pages 23 and 24 of the Paris Codex provide computing schemes to predict their movements in the sky. Perhaps the manuscript offers a means by which unpredicted, and potentially harmful interactions with them could be evaded. This is also why they are mentioned in those sections of Chilam Balam that describe the influence of zodiacal signs on different body parts. The Books of Chilam Balam provide evidence that European uses of astrology in curing activities were widely acknowledged. The heavenly bodies (the seven planets and twelve zodiacal signs) influenced different body parts in European medical astrology. Accordingly, the Reportorios de los tiempos and Lunarios printed this information to know when to perform curative procedures such as purging or bleeding. Recent scholarship (Bricker and Miram 2002; Caso Barrera 2011; George Hirons 2015) proved that texts on medical astrology contained in the Books of Chilam Balam derived from those European sources. Those astrological-medical contents were of interest to Maya elites in the 16th-19th centuries because they bore similarities to their traditional lore. A short note on ah chibal canob inserted between sections presenting the influence of the planets and zodiacal signs on parts of the human body supports the idea that they were attempting to correlate them with European concepts.

This proposal does not deny that animal figures devouring eclipse glyphs could have been identified with zodiacal or circum-zodiacal constellations. As creatures resided in the night and associated darkness, and cold, they emerged and preyed in the twilight hours just before sunrise. Indeed, one might say that watching the rising and setting stars in the early morning exposed human bodies to the poisonous action of celestial wahy-like beings.

\section{Possible identifications arising from contemporary ethnography}

Support for those ideas may be found in reports concerning the beliefs about animals causing sickness or sharp pain (chi'bal) recorded in the current ethnographic literature. 
For example, according to Tozzer (1907: 158), Redfield and Villa Rojas (1962:206) and Villa Rojas (1987:447), the Maya of Yucatan and Quintana Roo believe that certain "very bad animals" called kakazbaal who bite the sun and moon to cause the eclipses may also cause sharp pain to people. A Yucatec cosmic model recorded near Valladolid places ahkakazbalob, "bad spirits" in the third layer in seven-layered heaven (Tozzer 1907: 155). The notion of k'aak'as ba'al (translated as "bad thing", Quintal et al., 2013: 161) as an agent that provokes sickness is still found in the same region. However, today it seems to be divorced from the idea of malevolent animals producing eclipses.

Some Tzotzil from San Pedro Chenalho preserved the belief that the sky is the residence of thirteen malign spirits that take the form of animals (jaguar, falcon, and the like) and, as a whole, became personified by a jaguar or an eclipse. Their poisonous bite resembles fire (Guiteras Holmes 1996: 225-226). Though this account does not explicitly link the animals with stars, the description of celestial animals as biting agents (causing fiery effects, possibly inflammations, burning, and the like, see Helmke and Nielsen 2009: 67) resembles much of the Chilam Balam descriptions. Moreover, the number "thirteen" is very symptomatic in this context since it could well refer to the thirteen steps of the heavens. While commenting on this record, Sotelo Santos (1988: 22) supposed this belief was rooted in pre-Hispanic traditions. Another Tzeltal account from San Pablo Chalchihuitan records thirteen hnitkaros, or animate beings, who drag the sun god car and send diseases to humans (Kohler 1995: 134). They are conceived as a sub-group of holomal beings, widely identified with the lab entities in modern ethnographic publications (Pitarch 1996) and way beings in Yucatan (Villa Rojas 1985:105).

It may be proposed that in Maya traditional celestial lore, the hypothetical ecliptical constellations embodied, personified, or represented the spiritual wahylike entities that brought disease or malady. Their mode of being and interacting with people allowed the Maya elite members to compare them with actions produced by zodiacal signs, which corresponded to the twelve constellations occupying twelve equal parts of the ecliptic in Western medical astrology. Thus, both systems appear to share some superficial similarities, though they derive from different ontological frames.

In addition to the issues discussed above, the reasons for the appearance of thirteen Maya constellations should be examined. Although the similarity to the zodiac consisting of 13 constellations may be striking, instead, this number may be derived from the idea of thirteen different wahy-like beings. In this context, it is essential to remember that ethnographical evidence shows the contemporary Maya believe in thirteen different spiritual entities (or labs) manifested in the human world. 


\section{Conclusions}

According to the traditional scholarship, pages 23 and 24 of the Paris Codex represent thirteen Maya zodiacal constellations overlapping Western ecliptic ones. Considering Maya constellations as a kind of counterpart to the Western zodiac, scholars attempted to identify the figures of animals, list them in the correct order and match them with Western zodiacal constellations. Their research reflected a fundamental Cartesian ontology, where many worldviews (many cultures) describe the same single world (nature). Nevertheless, we lack a proper understanding of what those hypothetical constellations represented to the ancient Maya. In this article, I have proposed that the Maya developed a term for a category of wahybeings that acted in the twilight hours, inflicting diseases onto people. The Books of Chilam Balam use the term ah chibal canob. Thus, launching thirteen celestial animals embodying wahy- entities may correspond to the development of organizational categories of those entities rather than to the previously determined division of the ecliptic into thirteen formal constellations.

Pages 23-24 of the Codex display the dynamic field of stellar observations within which rising and setting constellations, more or less person-like, continually interacted with humans. The twilight hours constituted particular fields of relationships in which circum-ecliptic clusters of stars acted upon humans, as Bricker and Bricker's (2011) might imply. Particular constellations represented harmful or threatening attributes of the wahy-beings: skeletons, bats, snakes, jaguars, and unnatural beings connected with blood, death, and sacrifice, such as eagles, hawks, or centipedes whose bite resembled the fire, or owls whose song heralded ill omen.

Ah chibal canob beings differ from other known wahy-like entities. As biting/ devouring eclipse signs entities, possibly revealing them as eclipse agents of some sort, they manifest themselves as dangerous entities causing a particular kind of illness or disease. The life of ah chibal canob is given by the rotating skies because, in Mesoamerica, the capacity to move was essential to determine the animacy of entities (Bassett 2015: 13). Nevertheless, their relationship to humans was not defined a priori; it must be constructed or structured through calendric prediction/divination. In light of the analysis presented by Bricker and Bricker (2011), the moments when the zodiacal constellations rose and set simultaneously just before the sunrise may be interpreted as a temporal frame in which their interaction with humans took place. Thus, their harmful influence on humans was limited to the twilight hours. It follows that calendric prediction/divination/manipulation presented ah ch'ibal canob as acting subjects while the twilight hours constructed relational fields where they displayed their evil character.

The association of ah chibal canob with particular groups of stars located within or near the ecliptic reflects the Maya/Mesoamerican idea of particular celestial constellations regarded as animate beings. The Maya believed the sky was populated with different categories of beings. Celestial beings (animate entities associ- 
ated with the astronomical objects) fall into the four following categories (or groups, Iwaniszewski 2016):

1. Entities acting as autonomous beings, embodying the sun, the moon, and in later periods, the Morning Star.

2. Entities that originally inhabited human bodies but after death were projected onto the sky and eventually became absorbed by the sun and moon (tonalli or baah-like animate entities (souls)).

3. Objects associated with creation stories (mamalhuaztli, three stones...)

4. Circum-zodiacal constellations, belonging to wahy-like entities.

\section{Notes}

1 It is easy to calculate that the average daily value of the Sun's movement on the ecliptic is $360^{\circ} / 365.2422 \mathrm{~d}=0.9856^{\circ} /$ day. Hence 168 days $=170.4545^{\circ}$.

2 The following formula gives the duration of twilight:

$\operatorname{Cos} t=((\sin h-\sin \delta \sin \varphi):(\cos \delta \cos \varphi))$, where $h=-6^{\circ}$ denotes the beginning of the civil twilight, $\mathrm{h}=-12$, the start of the nautical twilight, and $\mathrm{h}=-18^{\circ}$, the commencement of the astronomical twilight, (Mietelski 1979:95).

3 For this paper, it is not crucial whether the constellations in the Paris Codex exactly match the zodiac understood as the band around the ecliptic within which the sun, moon, and planets move (see Love 2015:12 n2).

4 Gubler and Bolles (2000) translate chibil as "pain", Caso Barrera (2011) as "sting" (picadura), while Suarez Castro (2017) as "biting pain" (dolor mordiente).

\section{References}

Bassett Molly H.

2015 The Fate of Earthly Things: Aztec Gods and God-Bodies. University of Texas Press. https://doi.org/10.7560/760882

Bricker, Victoria R and Helga-Maria Miram

2002 An Encounter of Two Worlds: The Book of Chilam Balam of Kaua [Middle American Research Institute, Publication 68]. Tulane University, New Orleans.

Bricker, Harvey M. and Victoria R. Bricker

1992 Zodiacal references in the Maya codices. In The Sky in Mayan Literature, edited by. Anthony F. Aveni, pp. 148-183. Oxford University Press, New York.

2011 Astronomy in the Maya Codices. [Memoirs of the American Philosophical Society, Vol. 265]. American Philosophical Society, Philadelphia.

Carlson, John B. and Linda C. Landis

1985 Bands, Bicephalic Dragons, and Other Beasts: The Skyband in Maya Art and Iconography. In Elizabeth P. Benson (volume editor) Fourth Palenque Round Table, pp. 115-140. Pre-Columbian Art Research Institute, San Francisco.

Caso Barrera, Laura

2011 Chilam Balam de Ixil. Facsimilar y estudio de un libro maya inédito. Artes de México and Instituto Nacional de Antropología e Historia, México.

Chávez Guzmán, Mónica

2006 El sol como fundamento curativo de las terapias mayas yucatecas en el período colonial. Estudios de Cultura Maya 28: 121-139. 
Chevalier, Jacques M. and Andrés Sánchez Bain

2003 The Hot and the Cold: Ills of Humans and Maize in Native Mexico. University of Toronto Press, Toronto.

Chinchilla Mazariegos, Oswaldo

2011 Imágenes de la Mitología Maya. Museo Popol Vuh, Universidad Francisco Marroquín, Guatemala.

Closs, Michael P.

1989 Cognitive aspects of ancient Maya eclipse theory. In A.F. Aveni (ed.) World Archaeoastronomy, pp. 389-415. Cambridge University Press, Cambridge.

Craine, Eugene R. and Reginald C. Reindorp

1979 The Codex Pérez and the Book of Chilam Balam of Mani. University of Oklahoma Press, Norman.

Descola, Philippe

2014 Modes of being and forms of predication. HAU: Journal of Ethnographic Theory 4(1): 271-280. https://doi.org/10.14318/hau4.1.012.

George-Hirons, Amy

2015 Yokol Cab: Mayan Translation of European Astrological texts and Images in the Book of Chilam Balam of Kaua. Ethnohistory 62(3): 525-552. https://doi. org/10.1215/00141801-2890247

Grube, Nikolai and Werner Nahm

1994 A Census of Xibalba: A Complete Inventory of Way Characters in Maya Ceramics. In Justin Kerr (ed.), The Maya Vase Book. Kerr, New York, Vol. 4: 686-715.

Gubler, Ruth and David Bolles

2000 The Book of Chilam Balam of Na. Facsimile, Translation, and Edited Text. Labyrinthos, Holline Court.

Guiteras Holmes, Calixta

1996 Los peligros del alma. Visión del mundo de un tzotzil. Fondo de Cultura Económica, México. (primera edición en español en 1965, en inglés 1991).

Helmke, Christophe and Jesper Nielsen

2009 Hidden Identity and Power in Ancient Mesoamerica: Supernatural Alter Egos as Personified Diseases. Acta Americana 17(2): 49-98.

Iwaniszewski, Stanislaw

2009 Por una astronomía cultural renovada. Complutum 20(2): 39-54.

2011 The sky as a social field. In Clive L.N. Ruggles (ed.), Archaeoastronomy and Ethnoastronomy: Building Bridges Between Cultures. (IAU Symposium Proceeding Series, 278). Cambridge University Press, Cambridge, pp. 30-37.

2016 They Were Like Them: The Stars in Mesoamerican Imagery. In Nicholas Campion (ed.), Heavenly Discourses. Proceedings of the Heaving Discourses conference, Bristol 2011. Sophia Centre, University of Wales, Coredigion, pp. 51-59.

Kelley David H.

1976 Deciphering the Maya Script. University of Texas Press, Austin.

Klinger, Christian and Catherine Letcher Lazo

2012 The Role and Function of Wáay-Beings in the Context of Present-Day Yucatec Maya Life. In Maya Daily Lives: Proceedings of the 13th European Maya Conference, pp. 139-148. Verlag Anton Saurwein 
Knowlton, Timothy W.

2010 Maya Creation Myths. Words and Worlds of the Chilam Balam. University Press of Colorado, Boulder.

2015 Literacy and Healing: Semiotic Ideologies and the Entextualization of Colonial Maya Medical Incantations. Ethnohistory 62(3): 573-595. https://doi. org/10.1215/00141801-2890247

Köhler, Ulrich

1995 Chonbilal Chiulelal- Alma vendida. Elementos fundamentales de la cosmología y religión mesoamericanas en una oración en maya-tzotzil. Instituto de Investigaciones Antropológicas, Universidad Nacional Autónoma de México, México.

Love, Bruce

1994 The Paris Codex. Handbook for a Maya Priest. University of Texas Press, Austin.

2015 A Skyband with Constellations: Revisiting the Monjas East Wing at Chichen Itza. The PARI Journal 15(3): 11-14.

2018 The „Eclipse glyph” in Maya Text and Iconography: a Century of Misinterpretation. Ancient Mesoamerica 29: 219-244. https://doi.org/10.1017/S0956536116000444

Mietelski, Jan

1979 Astronomia w geografii. Państwowe Wydawnictwo Naukowe, Warszawa.

Milbrath, Susan

1999 Star Gods of the Maya. Astronomy in Art, Folklore, and Calendars. University of Texas Press, Austin.

Montoliú Villar, María

1989 Cuando los Dioses Despertaron. Conceptos cosmológicos de los antiguos mayas de Yucatán estudiados en el Chilam Balam de Chumayel. Instituto de Investigaciones Antropológicas, Universidad Nacional Autónoma de México.

Paxton, Merideth

1992 The Books of Chilam Balam: Astronomical Content and the Paris Codex. In The Sky in Mayan Literature, edited by. Anthony F. Aveni, pp. 216-246. Oxford University Press, New York

Pérez, Juan Pio

1949 Códice Pérez. Traducción de Ermilo Solís Alcalá. Imprenta Oriente, Mérida.

Prager, Christian

2006 Is T326 a logograph for NA;M "hide, to go out of sight". Notes on Ancient Maya Writing. Electronic document http://www.academia.edu /8219716/

Quintal, Ella F., Fidencio Briceño and Alejandro Cabrera

2013 Los que hablan con los vientos: los Jmeenoob. In Miguel A. Bartolomé and Alicia M. Barabas (eds.) ,Los sueños y los días: chamanismo y nahualismo en el México actual. Vol. II Pueblos Mayas, pp. 143-198. Instituto Nacional de Antropología e Historia, México.

Redfield, Robert and Alfonso Villa Rojas

1962 Chan Kom: A Maya Village. The University of Chicago Press, Chicago (first published in 1934).

Shesheña, Alejandro

2010 Los nombres de los naguales en la escritura jeroglífica maya: Religión y lingüística a través de la onomástica 1. Journal of Mesoamerican Languages and Linguistics 2(1): 1-30. 
Sotelo Santos, Laura Elena

1988 Las ideas cosmológicas mayas en el siglo XVI [Cuaderno 19], Centro de Estudios Mayas. Universidad Nacional Autónoma de México, México.

Smither, Robert K.

2012-13Correlation between Images in the Paris Codex and Stone Carvings at Chichén Itzá. Archaeoastronomy. The Journal of Astronomy in Culture 25: 30-53.

Spinden, Herbert J.

1916 The Question of the Zodiac in America. American Anthropologist N.S. 18, 1:53-80

Špoták, Jakub

2015 The Paris Codex: Complex Analysis of Ancient Maya Manuscript. Dissertation Thesis. Department of Comparative Religion, Faculty of Arts, Comenius University, Bratislava.

Stuart, David

2005 “The Way Beings". In Notebook for 29 $9^{\text {th }}$ Maya Hieroglyphic Forum at Texas. Department of Art and Art History, the College of Fine Arts, and the Institute of Latin American Studies. The University of Texas at Austin, pp. 160-165.

Suárez Castro, María de Guadalupe

2017 El Chilam Balam de Tekax. Análisis etnohistórico. Secretaría de Cultura, Instituto Nacional de Antropología e Historia, México.

Taube, Karl A.

2003 Ancient and contemporary Maya conceptions about field and forest. In: Arturo Gómez-Pompa (ed.), The Lowland Maya area: three millennia at the human-wildland interface. New York, pp. 461-492.

Tedlock, Barbara

1992a Time and the Highland Maya. Revised Edition. University of New Mexico, Albuquerque.

1992b The Road of Light: Theory and Practice of Mayan Skywatching. In Anthony F. Aveni (ed.), The Sky in Mayan Literature. Oxford University Press, New York, pp. 18-42 .

Tozzer, Alfred M.

1907 A Comparative Study of the Mayas and the Lacandones. The Archaeological Institute of America. Macmillan Co.. New York.

Villacorta C., J. Antonio and Carlos A. Villacorta

1933 Códices mayas: Dresdensis, Peresianus Tro-Cortesianus. Tipografía Nacional, Guatemala. Villa Rojas, Alfonso,

1987 Los Elegidos de Dios. Etnografía de los mayas de Quintana Roo. Instituto Nacional Indigenista, México.

Viveiros de Castro, Eduardo

1998 Cosmological Deixis and Amerindian Perspectivism. The Journal of the Royal anthropological Institute, N.S. 4(3): 469-488.

2004 Perspectivismo y multinaturalismo en la América Indígena. In Alexandre Surrallés and Pedro García Hierro (eds.), Tierra Adentro: territorio indígena y percepción del entorno. Grupo Internacional de Trabajo Sobre Asuntos Indígenas (IWGIA), Documento no. 39. Copenhague, pp. 37-80.

Whalen, Gretchen

2003 An Annotated Translation of a Colonial Yucatec Manuscript: On Religious and Cosmological Topics by a Native Author. FAMSI Reports. 